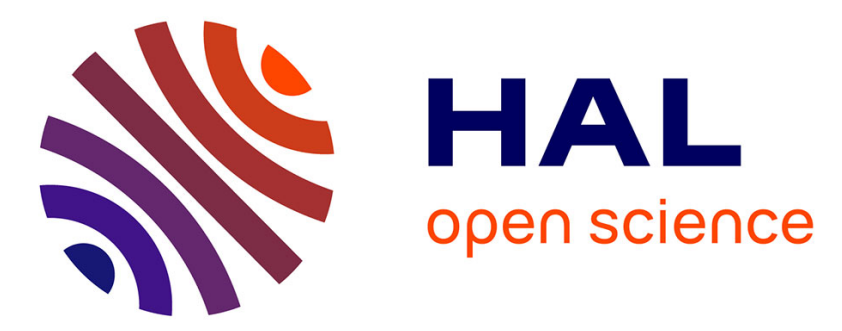

\title{
Lead, mercury, and selenium alter physiological functions in wild caimans (Caiman crocodilus)
}

Jérémy Lemaire, Paco Bustamante, R. Mangione, O. Marquis, C. Churlaud, Maud Brault-Favrou, Charline Parenteau, Francois Brischoux

\section{To cite this version:}

Jérémy Lemaire, Paco Bustamante, R. Mangione, O. Marquis, C. Churlaud, et al.. Lead, mercury, and selenium alter physiological functions in wild caimans (Caiman crocodilus). Environmental Pollution. Series A, Ecological and Biological, 2021, 286, pp.117549. 10.1016/j.envpol.2021.117549 . hal-03251504

\section{HAL Id: hal-03251504 \\ https://hal.science/hal-03251504}

Submitted on 11 Jan 2022

HAL is a multi-disciplinary open access archive for the deposit and dissemination of scientific research documents, whether they are published or not. The documents may come from teaching and research institutions in France or abroad, or from public or private research centers.
L'archive ouverte pluridisciplinaire HAL, est destinée au dépôt et à la diffusion de documents scientifiques de niveau recherche, publiés ou non, émanant des établissements d'enseignement et de recherche français ou étrangers, des laboratoires publics ou privés. 
Lead, mercury, and selenium alter physiological functions in wild caimans (Caiman crocodilus)

Jérémy Lemaire ${ }^{1-2}$, Paco Bustamante ${ }^{2-3}$, Rosanna Mangione ${ }^{4}$, Olivier Marquis ${ }^{5}$, Carine

Churlaud $^{2}$, Maud Brault-Favrou², Charline Parenteau' ${ }^{1}$, François Brischoux ${ }^{1}$

${ }^{1}$ Centre d'Études Biologiques de Chizé (CEBC), UMR 7372 CNRS-La Rochelle Université, 79360

Villiers en Bois, France

${ }^{2}$ Littoral Environnement et Sociétés (LIENSs), UMR 7266 CNRS-La Rochelle Université, 2 rue Olympe de Gouges, 17000 La Rochelle, France

${ }^{3}$ Institut Universitaire de France (IUF), 1 rue Descartes 75005 Paris, France

${ }^{4}$ Division of Behavioural Ecology, Institute of Ecology and Evolution, University of Bern, Wohlenstrasse 50a, CH-3032 Hinterkappelen, Switzerland

${ }^{5}$ Sorbonne Université, Muséum national d'Histoire naturelle, Parc Zoologique de Paris, 53 avenue de Saint Maurice, 75012 Paris, France

Corresponding author: jeremy.lemaire@univ-Ir.fr

Centre d'Études Biologiques de Chizé (CEBC), UMR 7372 CNRS-La Rochelle Université, 79360 Villiers en Bois, France 


\section{Abstract}

Environmental contaminants affect ecosystems worldwide and have deleterious effects on biota. Non-essential mercury $(\mathrm{Hg})$ and lead $(\mathrm{Pb})$ concentrations are well documented in some taxa and are described to cause multiple detrimental effects on human and wildlife. Additionally, essential selenium (Se) is known to be toxic at high concentration but, at lower concentrations, Se can protect organisms against Hg toxicity. Crocodilians are known to bioaccumulate contaminants. However, effects of these contaminants on physiological processes remain poorly studied. In the present study, we quantified $\mathrm{Hg}, \mathrm{Pb}$ and $\mathrm{Se}$ concentrations in spectacled caimans (Caiman crocodilus) and investigated effects of these contaminants on several physiological processes linked to osmoregulatory, hepatic, endocrine and renal functions measured through blood parameters in 23 individuals. Mercury was related to disruption of osmoregulation (sodium levels), hepatic function (alkaline phosphatase levels) and endocrine processes (corticosterone levels). Lead was related to disruption of hepatic functions (glucose and alanine aminotransferase levels). Selenium was not related to any parameters, but the $\mathrm{Se}: \mathrm{Hg}$ molar ratio was positively related to the $\mathrm{Na}^{+}$and corticosterone concentrations, suggesting a potential protective effect against $\mathrm{Hg}$ toxicity. Overall, our results suggest that $\mathrm{Hg}$ and $\mathrm{Pb}$ alter physiological mechanisms in wild caimans and highlight the need to thoroughly investigate the consequences of trace element contamination in crocodilians.

Keywords: Blood chemistry, Trace elements, Crocodilians, Corticosterone, Osmoregulation 


\section{INTRODUCTION}

Environmental contamination is recognized to be a widespread phenomenon, leading to increasing concerns as to its potential impact on biodiversity (Fleeger et al., 2003; EaglesSmith et al., 2018; Brühl and Zaller, 2019; Ferronato and Torretta, 2019; Pain et al., 2019; Kasonga et al., 2021). Environmental contaminants have multiple sources, and their recent increase mainly relates to anthropogenic activities such as fossil fuel combustion, chemical production and use, and mining activities (Richardson and Kimura, 2017). In addition, global changes have recently been identified as a cause of modification in the distribution and behaviour of environmental contaminants at a global scale (Noyes et al., 2009; Obrist et al., 2018). Providing information on environmental contamination levels and distribution across geographical areas, biomes or species is critical. One of the current challenges is to quantify how environmental contaminants affect physiological functions in various organisms and to understand the potential consequences for wildlife and human health.

Mercury $(\mathrm{Hg})$ and lead $(\mathrm{Pb})$ are two non-essential trace elements which are present in ecosystems worldwide and induce deleterious effects on humans and wildlife (Clarkson and Magos, 2006; Wani et al., 2015; Evers, 2018; Pain et al., 2019). They naturally occur in the environment, though human activities increase their levels (e.g., fuel combustion, mining activities and ammunition from hunting, Fisher et al., 2006; Pirrone et al., 2010; Beckers and Rinklebe, 2017; Fry et al., 2020). In addition, $\mathrm{Hg}$ and $\mathrm{Pb}$ bioaccumulate in various tissues of organisms (Vizuete et al., 2018; De Almeida Rodrigues et al., 2019; Pain et al., 2019). They have multiple adverse effects on reproductive, renal and hepatic functions, and are recognized as immune and endocrine disruptors (Eisler 1988; Fingerman et al., 1996; Pattee and Pain, 2003; Zahir et al., 2005; Scheuhammer et al., 2008; Tan et al., 2009; Grillitsch and 
Schiesari, 2010; Bergeron et al., 2011; Hopkins et al., 2013; Tartu et al., 2013; Whitney and Cristol, 2017; Monclús et al., 2020).

Selenium (Se) is an essential trace element which is involved in functions of various physiological processes, such as immune system and thyroid hormone homeostasis (Roy et al., 1995; Ramauge et al., 1996; Köhrle et al., 2005; Avery and Hoffmann, 2018; Qian et al., 2020). Its sources are both natural and anthropogenic with major releases into the environment from coal combustion (Rowe et al., 2002; Lemly, 2004; He et al., 2018; Ullah et al., 2019). A disruption of the normal Se balance can negatively affect metabolic processes (Rayman, 2000; Taylor et al., 2009; Finger et al., 2016). Selenium toxicity is known to affect growth, reproduction, and the immune system (Heinz et al., 1987; Hoffman et al., 1991; Hoffman, 2002; Hopkins et al., 2004; Naderi et al., 2021). Nevertheless, due to its high affinity to $\mathrm{Hg}$, Se qualifies as a natural antagonist: Low Se concentrations can protect organisms against toxic effects of $\mathrm{Hg}$ by reduction or even elimination of its toxicity (Sugiura et al., 1978; Gajdosechova et al., 2018; Rahman et al., 2019).

Crocodilians, being apex predators, accumulate high levels of metal contaminants due to their life history characteristics (e.g. aquatic habitat, long lifespan, high trophic level, high tissue conversion rate) and can serve as indicators of ecosystem health (Yanochko et al., 1997, Vieira et al., 2011; Schneider et al., 2015; Somaweera et al., 2020; Lemaire et al., 2021a). However, many crocodilians have a concerning conservation status, and populations of several species are currently decreasing (Targarona et al., 2008; Ferreira and Pienaar, 2011; Bezuijen et al., 2012; Van Weerd et al., 2016; Balaguera-Reina et al., 2018; Ortiz et al., 2020). Few studies which focused on a limited number of species have evaluated $\mathrm{Pb}$ and $\mathrm{Hg}$ concentrations in 
crocodilians (Burger et al., 2000; Jeffree et al., 2001; Correia et al., 2014; Trillanes et al., 2014; Nilsen et al., 2017b). Further knowledge on their negative effects is restricted to four crocodilian species (Alligator mississippiensis, Caiman crocodilus, Paleosuchus trigonatus and Crocodylus niloticus) and few markers (morphology, DNA and reproduction; Lance et al., 2006; Warner et al., 2016; Nilsen et al., 2017a; Marrugo-Negrete et al., 2019; Lemaire et al., 2021b). To our knowledge, no studies have investigated the combined effects of $\mathrm{Hg}, \mathrm{Pb}$ and $\mathrm{Se}$, and the possible protective effect of Se on physiological parameters of caimans, particularly in French Guiana, where said contaminants are highly abundant in the environment.

To investigate potential effects of such contaminants on physiological functions of humans and wildlife, blood chemistry analysis is a relevant tool. Blood integrates indices of most organisms' physiological processes. Therefore, blood chemistry offers a generalist approach to investigate several physiological functions (e.g., energetic metabolism, reproduction, detoxification, osmoregulation; Aguiree and Balazs, 2000; Brischoux and Kornilev, 2014; Barão-Nóbrega et al., 2018; Hudson et al., 2020) and can additionally be used for contamination level assessment (Clark et al., 2000). Because blood sampling is non-lethal and performed relatively easily, the effect of trace elements on biochemical parameters can be monitored over time.

In the present study, we assessed the concentrations of selected trace elements $(\mathrm{Hg}, \mathrm{Pb}$, and Se) and 15 physiological parameters indicative of osmoregulatory (e.g., sodium, chlorine), metabolic (e.g., glucose, calcium), hepatic (e.g., aspartate aminotransferase, alanine aminotransferase), endocrine (e.g., corticosterone) and renal (e.g., total protein) functions in the blood of Caiman crocodilus from French Guiana. Additionally, we evaluated relationships 
between $\mathrm{Hg}, \mathrm{Pb}$, and $\mathrm{Se}$ with blood chemistry and corticosterone to investigate the effects of these trace elements on crocodilian physiology.

\section{MATERIAL AND METHODS}

\subsection{Sample collection}

Between November 2019 and February 2020, we captured and sampled 23 Spectacled Caimans Caiman crocodilus at "Pripis de Yiyi" (N $05^{\circ} 25^{\prime} 25^{\prime}$, W $53^{\circ} 02^{\prime} 50^{\prime \prime}$ ) and the nature

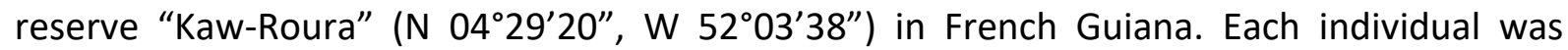
measured (Snout-Vent Length, SVL) and weighed. Blood was drawn from the lateral tail vein using a $2.5 \mathrm{~mL}$ syringe and a 23 or 21 gauge $-50 \mathrm{~mm}$ heparinized needle (heparin sodium). Due to logistical constraints inherent to field procedures and the study species, time between the successful capture of an individual and the end of blood sampling was $14 \pm 3$ minutes (range 10 - 19 minutes). Blood samples were immediately placed in cold temperatures $\left(4^{\circ} \mathrm{C}\right)$ until being processed at the laboratory. After biochemistry analysis (see below), half of the whole blood was frozen at $-28^{\circ} \mathrm{C}$, the second part was centrifuged at $6500 \mathrm{rpm}$ for 5 minutes, then plasma and red blood cells were separately frozen at $-28^{\circ} \mathrm{C}$.

After sampling, all caimans were released at their capture locations. Captures and sample collection were performed under a permit from the French authorities (Direction Régionale des Territoires et de la Mer) after evaluation by the CSRPN, the regional scientific committee (Permit: R03-2019-01-09-001 \& R03-2019-10-24-007).

\subsection{Blood biochemistry analysis}

An average of four hours after sampling, we analyzed blood parameters using VetScan VS2 Chemistry Analyzer (Abaxis, Inc., Union City, California, USA) by applying $100 \mu \mathrm{L}$ of whole blood 
on "Avian-Reptilian" and/or "Preventive Care Profile Plus" designated rotors to measure total calcium $\left(\mathrm{Ca}^{++}\right)$, potassium $\left(\mathrm{K}^{+}\right)$, sodium $\left(\mathrm{Na}^{+}\right)$, chloride $\left(\mathrm{Cl}^{-}\right)$, phosphorus $(\mathrm{P})$, uric acid $(\mathrm{UA})$, glucose $(G L U)$, total bilirubin (TBIL), total protein (TP), creatine kinase (CK), aspartate aminotransferase (AST), alanine aminotransferase (ALT), albumin (ALB), alkaline phosphatase (ALP), total carbon dioxide $\left(\mathrm{tCO}_{2}\right)$, blood urea nitrogen (BUN), bile acids (BA), creatinine (CRE) and globulin (GLOB). Five blood biochemistry parameters (ALB, BUN, CRE, BA and GLOB) could not be quantified as their levels were under the detection limit of the VetScan.

\subsection{Corticosterone analysis}

We measured plasma corticosterone levels using radioimmunoassay, as described in Lormée et al., (2003). Corticosterone was measured after ethyl ether extraction using a commercial antiserum. After adding dextran-coated charcoal and centrifugation, the free corticosterone was separated. Bound fraction containing corticosterone was measured using a liquid scintillation counter. The minimum detectable corticosterone concentration was $0.28 \mathrm{ng} \cdot \mathrm{ml}^{-}$ 1 , and the inter-assay coefficients of variation were $6.24 \%$ and $9.63 \%$ respectively (samples were assayed in duplicate, in two assays).

\subsection{Trace element analysis}

Whole blood was freeze-dried for 48 hours, ground and homogenized. Total $\mathrm{Hg}$ concentrations were determined by direct measurement in the whole blood, using an atomic absorption spectrometer AMA-254 (Advanced Mercury Analyser-254; Altec ${ }^{\circledR}$ ). Certified Reference Material (CRM) TORT-3 (lobster hepatopancreas; certified Hg concentration: 0.292 $\pm 0.022 \mu \mathrm{g} \cdot \mathrm{g}^{-1}$ dry weight $\left.(\mathrm{dw}), \mathrm{NRCC}\right)$ was analyzed at the beginning and at the end of the analytical cycle to validate the method. For each individual, two replicates of blood $(\sim 0.6 \mathrm{mg}$ 
$d w)$ were analyzed, and the reproducibility for replicate samples was approved when the relative standard deviation (RSD) was $<10 \%$. Measured values for TORT-3 were $0.292 \pm 0.006$ $\mu g \cdot g^{-1} d w(n=20)$, with a recovery of $100.1 \pm 1.9 \%$. The limit of quantification was $0.05 n g$. Se and $\mathrm{Pb}$ were analyzed in freeze-dried whole blood using Inductively Coupled Plasma Mass Spectrometry (ICP-MS II Series Thermo Fisher Scientific), (aliquots mass: 8 - 139 mg dw). Whole blood samples were microwave-digested in a mixture of $6 \mathrm{~mL}$ of $70 \% \mathrm{HNO}_{3}$ (VWR Quality SUPRAPUR) and $2 \mathrm{~mL}$ of $30 \% \mathrm{HCl}$ (VWR Quality SUPRAPUR); for samples weighing less than $100 \mathrm{mg}$, the volumes of $\mathrm{HNO}_{3}$ and $\mathrm{HCl}$ were divided by half. Samples were further diluted with ultrapure water to $50 \mathrm{~mL}$ ( $25 \mathrm{~mL}$ for samples $<100 \mathrm{mg}$ ). To avoid contamination, all utensils used were soaked in a bath of diluted nitric acid for at least $48 \mathrm{~h}$, rinsed in ultrapure water and dried. Certified Reference Materials (CRM; dogfish liver DOLT-3, NRCC, and lobster hepatopancreas TORT-2, NRCC) were treated and analyzed as samples. Results of $\mathrm{Hg}, \mathrm{Pb}$ and Se quantification were in agreement with the certified values, and the standard deviations were low, proving good repeatability of the methods. The results for CRMs displayed recoveries of the elements ranging from $92.1 \pm 17.5 \%(n=8)$ for $\mathrm{Pb}, 110.7 \pm 4.7 \%$ for $\mathrm{Se}(n=8)$. $\mathrm{Hg}, \mathrm{Pb}$ and Se results are further expressed in $\mu \mathrm{g} \cdot \mathrm{g}^{-1} \mathrm{dw}$.

\subsection{Statistical analyses}

All analyses were performed using the Software R v.3.6.1. ( $R$ development Core Team). The data was first checked for normality and homogeneity of variances. Analyses on trace elements were performed on log-transformed values. The Selenium:Mercury (Se:Hg) molar ratio was calculated using the $\mathrm{Hg}$ and Se concentrations (in $\mu \mathrm{g} \cdot \mathrm{g}^{-1} \mathrm{dw}$ ) divided by the molecular weight of each element, respectively 200.59 for $\mathrm{Hg}$ and 78.96 for Se, following the equation : 


$$
\text { Se: } H g \text { molar ratio }=\frac{\text { Se concentration }\left(\mu g \cdot g^{-1} d w\right) / 78.96}{H g \text { concentration }\left(\mu g \cdot g^{-1} d w\right) / 200.59}
$$

The relation between trace elements, biometric measurements, and biochemistry parameters were assessed by linear regression.

Corticosterone concentrations of Caiman crocodilus were not influenced significantly by the time of handling $\left(F_{2,18}=0.274, p=0.787\right)$ and relations between trace elements and corticosterone concentrations were assessed with linear regressions.

\section{RESULTS AND DISCUSSION}

Non-essential trace elements affected physiological parameters, in particular osmoregulatory, hepatic, endocrine and renal functions. Below we discuss the physiological mechanisms which appear to be potentially affected by these contaminants.

\subsection{Mercury}

$\mathrm{Hg}$ concentrations ranged from 0.168 to $1.532 \mu \mathrm{g} \cdot \mathrm{g}^{-1} \mathrm{dw}$ (Table 1 ) and were negatively correlated with natremia $\left(R^{2}=0.345, p=0.005\right.$, Fig.1, Table 2$)$ and, to a lesser extent with chloremia $\left(R^{2}=0.437, p=0.053\right)$. This suggests that higher $\mathrm{Hg}$ concentrations negatively influenced ionic regulation which is related to renal functions in caimans.

We found a negative relationship between $\mathrm{Hg}$ and alkaline phosphatase (ALP) concentrations $\left(R^{2}=0.601, p=0.024\right.$, Fig.1, Table 2). Elevation of $\mathrm{Hg}$ concentrations is linked to a diminution of ALP in the blood of Caiman crocodilus, suggesting an alteration of hepatic function.

Our results show a negative relationship between corticosterone levels and $\mathrm{Hg}$ concentrations $\left(R^{2}=0.276, p=0.021\right.$, Table 2$)$, which suggests that elevation of Hg concentrations may disrupt endocrine processes in caimans by a diminution of corticosterone production (HPA axis). 
Although $\mathrm{Hg}$ toxicity is well documented in several taxa (Scheuhammer et al., 2007; Morcillo et al., 2017; Evers, 2018; Zheng et al., 2019), its effects remain poorly studied in reptiles (Schneider et al., 2013). Hg can act as an inhibitor of the $\mathrm{Na}^{+} / \mathrm{K}^{+}$-ATPase (Kramer et al., 1986; Magour, 1986; Chuu et al., 2007), and can lead to a disruption of osmoregulation in taxa such as fishes and crustaceans (Lock et al., 1981; Bianchini and Gilles, 1996; Handayani et al., 2020). In Alligatorids, osmoregulation principally occurs in the kidneys (Mazzotti and Dunson, 1989; Grigg et al., 1998) and our results suggest that renal function may be negatively affected by Hg. Freshwater species need to maintain osmolality in a hyposmotic environment, as the regulation of the hydromineral balance is crucial for survival (Schmidt-Nielsen, 1983). Hyponatremia has been shown to cause neurological dysfunction, muscle damage and death (Patterson, 2011; Gankam Kengne and Decaux, 2018; Martemyanov and Pddubnaya, 2020, Arieff, 1986, 2006). Therefore, consequences of chronic hyponatremia in Hg-contaminated freshwater crocodilians needs to be assessed.

The negative relationship between $\mathrm{Hg}$ and ALP suggests that some liver functions in Caiman crocodilus are disrupted due to Hg contamination, as previously found in fish (Sastry and Sharma, 1980) and rodents (El-Shenawy and Hassan, 2008). ALP is a liver cytoplasmic enzyme involved in the hepatocytic functions, and perturbations of its activity occur via mechanisms such as ATPase disruption (El-Shenawy and Hassan, 2008). Potential effects of decreased ALP, and/or altered liver functions linked to $\mathrm{Hg}$ contamination in caimans deserve further investigation. 
Mercury accumulates in the pituitary gland and the thyroid and alters the endocrine system in vertebrates (Colborn et al., 1993; Tan et al., 2009; Meyer et al., 2014, Tartu et al., 2013). Consistent with these studies, the negative relationship between corticosterone levels and $\mathrm{Hg}$ concentration suggests that $\mathrm{Hg}$ may disrupt endocrine processes in caimans as already shown in other taxa (Moore et al., 2014; Meillère et al., 2016; Soto et al., 2019). Disruption of corticosterone levels has consequences on metabolism, behaviour and reproduction (Denardo and Licht, 1993; Guillette et al., 1995; Scott et al., 2019). Effects of environmental contaminants (e.g., pesticides, trace elements) on the endocrine system of crocodilians have been already reported (Guillette et al., 1994; Arukwe et al., 2016; Finger et al., 2018), while endocrine disruption associated to $\mathrm{Hg}$ contamination is yet unknown but demands future evaluation.

\subsection{Selenium and Se:Hg molar ratio}

Se concentrations ranged from 0.76 to $1.92 \mu \mathrm{g} \cdot \mathrm{g}^{-1} \mathrm{dw}$ (Table 1 ) and was not related to other parameters (all $p>0.05$, Table 2), suggesting that Se concentrations were not high enough to induce any effects.

Our results show that natremia $\left(\mathrm{Na}^{+}: \mathrm{R}^{2}=0.378, \mathrm{p}=0.004\right.$, Fig. 2 , Table 2 ) and corticosterone levels $\left(R^{2}=0.272, p=0.026\right.$, Table 2$)$ increased with the Se:Hg molar ratio. These results show that $\mathrm{Na}^{+}$and corticosterone levels are positively influenced by an excess of Se against $\mathrm{Hg}$, suggesting a potential positive effect of Se.

Selenium is an essential trace element involved in antioxidant defense and thyroid metabolism which can be toxic in high concentrations (Behne et al., 2000; Ramauge et al., 1996; Rayman, 2000). In the American alligator, Alligator mississippiensis, chronic Se exposure 
affects stress parameters such as corticosterone levels (Finger et al., 2019). Our results suggest that Se concentrations were not high enough to trigger toxic effects. However, the relationships found between Se:Hg molar ration and natremia and corticosterone levels suggests positive effects of this ratio. As already discussed, $\mathrm{Hg}$ concentrations show a negative relationship with $\mathrm{Na}^{+}$and corticosterone concentrations. Because Se reduces $\mathrm{Hg}$ toxicity in many taxa (Beijer and Jernolov, 1978; Freidman et al., 1978; Ohi et al., 1980; Culvin-Aralar and Furness, 1991; Suzuki, 1997; Ralston et al., 2006; Ralston and Raymond, 2010), we suggest that Se:Hg molar ratio has a role of protection against $\mathrm{Hg}$ toxicity in Caiman crocodilus. This hypothesis is reinforced by the marginal relationship detected between Se concentration and $\mathrm{Na}^{+}$values. Our results emphasize the need for future studies on this potential protective effect of the Se:Hg molar ratio in crocodilians.

\subsection{Lead}

$\mathrm{Pb}$ concentrations range from 0.04 to $0.28 \mu \mathrm{g} \cdot \mathrm{g}^{-1} \mathrm{dw}$ (Table 1 ) and were negatively related to glucose levels $\left(R^{2}=0.239, p=0.025\right.$, Fig.3, Table 2$)$, suggesting that $\mathrm{Pb}$ affects mechanisms related to the regulation of glucose. Our results show a positive relationship between $\mathrm{Pb}$ concentration and alanine aminotransferase (ALT) $\left(R^{2}=0.740, p=0.003\right.$, Fig.3, Table 2) suggesting that the organism increases the production of ALT in response to elevated $\mathrm{Pb}$ concentration in the blood.

The detrimental effects of lead contamination are well studied and affect vascular, nervous, renal, hepatic, immune, endocrine and reproductive systems (Eisler 1988; Pattee and Pain, 2003; Grillitsch and Schiesari, 2010). The biokinetics of Pb in the blood of crocodilians is shorter than in other vertebrates, with a half-life of 3 days, in comparison to 13 days in birds 
and mammals (Anders et al., 1982; Castellino and Aloj, 1964; Hammerton et al., 2003). No clinical signs of $\mathrm{Pb}$ toxicity were found in crocodilian studies yet, suggesting resistance of the taxon to the contaminant (Cook et al., 1988; Camus et al., 1998; Hammerton et al., 2003; Lance et al., 2006; Warner et al., 2016). However, our results show a negative relationship between $\mathrm{Pb}$ and glucose level suggesting that $\mathrm{Pb}$ affects the endocrine systems of Caiman crocodilus and alters its liver function. Glucose is regulated by the liver and complex interactions with the hypothalamus, pituitary and adrenal glands (Lin and Accili, 2011; Cady et al., 2017). Our results are consistent with studies in marine turtles exposed to $\mathrm{Pb}$ (Komoroske et al., 2011). Our findings are strengthened by the positive relationship we additionally found between $\mathrm{Pb}$ and $\mathrm{ALT}$, an indicator of hepatocellular damages (Kew, 2000; Maheswari et al., 2008). While our initial findings show some toxic effects of $\mathrm{Pb}$ on liver functions in crocodilians, it deserves further investigation.

\section{CONCLUSION}

The present study provides the first evidence that $\mathrm{Hg}$ and $\mathrm{Pb}$ affect physiological parameters in Caiman crocodilus. Mercury was related to disruptions of sodium, alkaline phosphatase, and corticosterone levels, which suggests a negative effect on osmoregulation, hepatic functions and endocrine processes. Lead was related to disruption of glucose and alanine aminotransferase levels, suggesting hepatocellular damages. Although the $\mathrm{Hg}$ and $\mathrm{Pb}$ concentrations of the present study are commonly found in crocodilians, the relationship between contaminant levels and blood parameters are of concern. Interestingly, results that investigate the Se:Hg molar ratio suggest a protective effect of Se against $\mathrm{Hg}$ toxicity in caimans. This study is a starting point for further evaluation of trace element consequences on physiological mechanisms in caimans, particularly those more vulnerable to exposure. 
Indeed, our sampled individuals were relatively small and thus probably young individuals which suggest that physiological alterations linked to non-essential trace elements can occur early in the life of crocodilians.

\section{Acknowledgements}

We would like to thank the teams of the nature reserves "Kaw-Roura", the protected area of "Pripris de Yiyi" and the conservatoire du littoral for logistics and assistance in the field. We would also like to thank Philippe Gaucher, Frédéric Beau, Laura Beau, Thibaut Foch, Fanny Veinante, Clarisse Lhez and Jennifer Devillechabrolle for their help in the field. We are grateful to Ashley Pearcy Buitenwerf for the English revision and valuable comment on the manuscript. This study was supported by the Office de l'Eau de Guyane (OEG), the Office Française pour la Biodiversité (OFB), the Direction Générale des Territoires et de la Mer de Guyane (DGTM), the Parc Zoologique de Paris, the CNRS and the Fondation d'entreprise Hermès. The CPER (Contrat de Projet Etat Région) and the FEDER (European regional Development Fund) are acknowledged for funding the Vetscan, the AMA and the ICP-MS of the Plateforme Analyses Elémentaires of the LIENSs laboratory. The Institut Universitaire de France (IUF) is acknowledged for its support to P. Bustamante as a Senior Member.

\section{REFERENCES}

Aguiree, A.A., Balazs, G.H. 2000. Blood biochemistry values of Green Turtles, Chelonia mydas, with and without fibropapillomatosis. Comp. Haematol. Int. 10, 132-137.

Anders, E., Dietz, D.D., Bagnell, C.R., Gaynor, J., Krigman, M.R., Ross, D.W., Leander, J.D., Mushak, P. 1982. Morphological, pharmacokinetic, and hematological studies of leadexposed pigeons. Environ. Res. 28, 344-363.

Arieff, A.I., 1986. Hyponatremia, convulsions, respiratory arrest, and permanent brain damages after elective surgery in healthy women. N. Engl. J. Med. 314, 1529-1535.

Arieff, A.I. 2006. Influence of hypoxia and sex on hyponatremic encephalopathy. Am. J. Med. $119,59-64$. 
Arukwe, A., Myburgh, J., Langberg, H.A., Adeogun, A.O., Braa, I.G., Moeder, M., Schlenk, D., Crago, J.P., Regoli, F., Botha, C. 2016. Developmental alterations and endocrine-disruptive responses in farmed Nile crocodile (Crocodylus niloticus) exposed to contaminants from the Crocodile River, South Africa. Aqua. Toxicol. 173, 83-93.

Avery, J.C., Hoffmann, P.R. 2018. Selenium, Selenoproteins, and Immunity. Nutrients 10(9), 1203.

Balaguera-Reina, S.A., Espinosa-Blanco, A., Antelo, R., Morales-Betancourt, M., Seijas, A. 2018. Crocodylus intermedius. The IUCN Red List of Threatened Species 2018: e.T5661A3044743.

Barão-Nóbrega, J.A.L., Marioni, B., Botero-Arias, R., Nogueira, A.J.A., Lima, E.S., Magnusson, W.E., Da Silveira, R., Marcon, J.L. 2018. The metabolic cost of nesting: body condition and blood parameters of Caiman crocodilus and Melanosuchus niger in Central Amazonia. J. Comp. Physiol. B 188, 127-140.

Beckers, F., Rinklebe, J. 2017. Cycling of mercury in the environment: Source, fate, and human health implications: A review. Crit. Rev. Env. Sci. Tec. 47(9), 693-794.

Behne, D., Pfeifer, H., Rothlein, D., Kyriakopoulos, A. 2000. Cellular and subcellular distribution of selenium and selenium-containing proteins in the rat. In: Roussel, A.M., Favier, A.E., Anderson, R.A. (Eds.), Trace Elements in Man and Animals 10. Kluwer Academic/Plenum Publishers, New York, pp. 29-34.

Beijer, K., Jernelov, A. 1978. Ecological aspects of mercury-selenium interaction in the marine environment. Environ. Health Perspect. 25, 43-45.

Bezuijen, M., Simpson, B., Behler, N., Daltry, J, Trempsiripong, Y. 2012. Crocodylus siamensis. The IUCN Red List of Threatened Species 2012: e.T5671A3048087.

Bergeron, C.M., Hopkins, W.A., Todd, B.D., Hepner, M.J., Unrine, J.M. 2011. Interactive effects of maternal and dietary mercury exposure have latent and lethal consequences for amphibian larvae. Environ. Sci. Technol. 45(8), 3781-3787.

Bianchini, A., Gilles, R. 1996. Toxicity and accumulation of mercury in three species of crabs with different osmoregulatory capacities. Bull. Environ. Contam. Toxicol. 57, 91-98.

Bruckner, J.V., Khanna, K.L., Cornish, H.H. 1973. Biological responses of the rat to polychlorinated biphenyls. Toxicol. Appl. Pharmacol. 24, 434-448.

Burger, J., Gochfeld, M., Rooney, A.A., Orlando, E.F., Woodward, A.E., Guillette Jr., L.J. 2000. Metals and metalloids in tissues of American Alligators in three Florida lakes. Arch. Environ. Contam. Toxicol. 38, 501-508. 
Brischoux, F., Kornilev, Y.V. 2014. Hypernatremia in Dice Snakes (Natrix tessellata) from a coastal population: implications for osmoregulation in marine snake prototypes. PLOS ONE 9(3): e92617.

Brühl, C.A., Zaller, J.G. 2019. Biodiversity decline as a consequence of an inappropriate environmental risk assessment of pesticides. Front. Environ. Sci. 7:177.

Cady, G., Landeryou, T., Garratt, M., Kopchick, J.J., Qi, N., Garcia-Galiano, D., Elias, C.F., Myers Jr., M.G., Miller, R.A., Sandoval, D.A., Sadagurski, M. 2017. Hypothalamic growth hormone receptor (GHR) controls hepatic glucose production in nutrient-sensing leptin receptor (LepRb). Mol. Metab. 6(5), 393-405.

Camus, A.C., Mitchell, M.M., Williams, J.F., Jowet, P.L.H. 1998. Elevated lead levels in farmed American alligators Alligator mississippiensis consuming nutria Myocastor coypus meat contaminated by lead bullets. J. World Aquac. Soc. 29, 370-376.

Castellino, N., Aloj, S. 1964. Kinetics of the distribution and excretion of lead in the rat. N. Brit. J. Ind. Med. 21, 308-314.

Chuu, J.J., Liu, S.H., Lin-Shiau, S.Y. 2007. Differential neurotoxic effects of methylmercury and mercuric sulfide in rats. Toxicol. Lett. 169(2), 109-120.

Clark Jr., D.R., Bickham, J.W., Baker, D.L., Cowman, D.F. 2000. Environmental contaminants in Texas, USA, wetland reptiles: evaluation using blood samples. Environ. Toxicol. Chem. 19, 2259-2265.

Clarkson, T.W., Magos, L. 2006. The toxicology of mercury and its chemical compounds. Crit. Rev. Toxicol. 36, 609-662.

Colborn, T., Vomsaal, F.S., Soto, A.M. 1993. Developmental effects of endocrine-disrupting chemicals in wildlife and humans. Environ. Health Perspect. 101, 378-384.

Cook, R., Behler, J., Braezitis, P., Dolensek, E. 1998. A survey of blood lead level in crocodilians. In: Stoskopf MK (Eds) International association for aquatic animal medicine proceedings, vol 19. W.B. Saunders, Philadelphia, pp. 149-150.

Correia, J., Cesar, R., Marsico, E., Diniz, G.T.N., Zorra, M.C., Castilhos, Z. 2014. Mercury contamination in alligators (Melanosuchus niger) from Mamirauá Reservoir (Brazilian Amazon) and human health risk assessment. Environ. Sci. Pollut. Res. 21, 13522-13527.

Culvin-Aralar, M.L., Furness, R.W. 1991. Mercury and selenium interaction: a review. Ecotoxicol. Environ. Saf. 21, 348-364. 
De Almeida Rodrigues, P., Ferrari, R.G., Dos Santos, L.N., Junior, C.A.C. 2019. Mercury in aquatic fauna contamination: a systematic review on its dynamics and potential health risks. J. Environ. Sci. 84, 205-218.

Denardo, D.F., Licht, P. 1993. Effects of corticosterone on social behavior of male lizards. Horm. Behav. 27, 184-199.

Eagles-Smith, C.A., Silbergeld, E.K., Basu, N., Bustamante, P., Diaz-Barriga, F., Hopkins, W.A., Kidd, K.A., Nyland, J.F. 2018. Modulators of mercury risk to wildlife and humans in the context of rapid global change. Ambio 47, 170-197.

Eisler, R. 1988. Lead hazards to fish, wildlife, and invertebrates: a synoptic review. Contaminant Hazard Reviews. U.S. Fish and Wildlife Service Biological Report, 85, 1-14.

El-Shenawy, S.M.A., Hassan, N.S. 2008. Comparative evaluation of the protective effect of selenium and garlic against liver and kidney damage induced by mercury chloride in the rats. Pharmacol. Rep. 60, 199-208.

Evers, D. 2018. The effects of methylmercury on wildlife; a comprehensive review and approach for interpretation. In: DellaSala, D.A. and Doldstein, M.I. (eds.) The Encyclopedia of the Antropocene, vol.5, p. 181-194. Oxford: Elsevier.

Ferreira, S.M., Pienaar, D. 2011. Degradation of the crocodile population in the Olifants River Gorge of Kruger National Parck, South Africa. Aquatic Conserv.: Mar. Freshw. Ecosyst. 21, 155-164.

Ferronato, N., Torretta, V. 2019. Waste mismanagement in developing countries: a review of global issues. Int. J. Environ. Res. Public Health 16, 160.

Finger Jr., J.W., Hamilton, M.T., Kelley, M.D., Stacy, N.I., Glenn, T.C., Tuberville, T.D. 2019. Examining the effects of chronic selenium exposure on traditionally used stress parameters in juvenile American Alligator (Alligator mississippiensis). Arch. Environ. Contam. Toxicol. 77, 14-21.

Finger Jr., J.W., Hamilton, M.T., Kelley, M.D., Zhang, Y., Kavazis, A.N., Glenn, T.C., Tuberville, T.D. 2018. Dietary Selenomethionine administration and its effects on the American Alligator (Alligator mississippiensis): Oxidative status and corticosterone levels. Arch. Environ. Contam. Toxicol. 75, 37-44.

Finger Jr., J.W., Hamilton, M.T., Metts, B.S., Glenn, T.C., Tuberville, T.D. 2016. Chronic ingestion of Coal Fly-Ash contaminated prey and its effects on health and immune 
parameters in juvenile American Alligators (Alligator mississippiensis). Arch. Environ. Contam. Toxicol. 71, 347-358.

Fingerman, M., Devi, M., Reddy, P.S., Katyayani, R. 1996. Impact of heavy metal exposure on the nervous system and endocrine-mediated processes in crustaceans. Zool. Stud. 35(1), 18.

Fisher, I.J., Pain, D.J., Thomas, V.G. 2006. A review of lead poisoning from ammunition sources in terrestrial birds. Biol. Conserv. 131, 421-432.

Fleeger, J.W., Carman, K.R., Nisbet, R.M. 2003. Indirect effects of contaminants in aquatic ecosystems. Sci. Total Environ. 317, 207-233.

Freidman, M.A., Eaton, L.R., Carter, W.H. 1978. Protective effects of freeze-dried swordfish on methylmercury chloride toxicity in rats. J. Environ. Contam. Toxicol. 19, 436-443.

Fry, K.L., Wheeler, C.A., Gillings, M.M., Flegal, A.R., Taylor, M.P. 2020. Anthropogenic contamination of residential environments from smelter $\mathrm{As}, \mathrm{Cu}$ and $\mathrm{Pb}$ emissions: Implications for human health. Environ. Pollut. 262, 114235.

Gajdosechova, Z., Mester, Z., Feldmann, J., Krupp, E.M. 2018. The role of selenium in mercury toxicity - Current analytical techniques and futures trends in analysis of selenium and mercury interactions in biological matrices. Trends Anal. Chem. 104, 95-109.

Gankam Kengue, F., Decaux, G. 2018. Hyponatremia and the brain. Kidney Int. Rep. 3, 24-35.

Grigg, G.C., Beard, L.A., Moulton, T., Queirol Melo, M.T., Taplin, L.E. 1998. Osmoregulation by the broad-snouted caiman, Caiman latirostris in estuarine habitat in southern Brazil. J. Comp. Physiol. B 168, 445-452.

Grillitsch, B., Schiesari, L. 2010. The ecotoxicology of metals in reptiles. In: Sparling, D.W., Linder, G., Bishop, C.A., Krest, S.K. (Eds.), Ecotoxicology of Amphibians and Reptiles. Society of Environmental Toxicology and Chemistry, pp. 337-448. Pensacola.

Guillette Jr, L.J., Cree, A., Rooney, A.A. 1995. Biology of stress: Interactions with reproduction, immunology and intermediary metabolism. In C. Warwirck, Frye, F.L., Murphy, J.B. (eds.), Health and Welfare of Captive Reptiles, pp. 32-81. Chapman and Hall, London.

Guillette Jr, L.J., Gross, T.S., Masson, G.R., Matter, J.M., Percival, H.F., Woodward, A.R. 1994. Developmental abnormalities of the gonad and abnormal sex hormone concentrations in juvenile Alligator from contaminated and control lakes in Florida. Environ. Health Perspect. 102(8), 680-688. 
Hammerton, K.M., Jayasinghe, N., Jeffree, R.A., Lim, R.P. 2003. Experimental study of blood lead kinetics in estuarine crocodiles (Crocodylus porosus) exposed to ingested lead shot. Arch. Environ. Contam. Toxicol. 45, 390-398.

Handayani, K.S., Soegianto, A., Lignot, J. 2020. Change of osmoregulatory and hematological parameters in tilapia (Oreochromis niloticus) after exposure to sublethal mercury concentrations. Emerg. Contam. 6, 337-344.

He, Y., Xiang, Y., Zhou, Y., Yang, Y., Zhang, J., Huang, H., Shang, C., Luo, L., Gao, J., Tang, L. 2018. Selenium contamination, consequences and remediation techniques in water and soils: $\mathrm{A}$ review. Environ. Res. 164, 288-301.

Heinz, G.H., Hoffman, D.J., Krynitsky, A.J., Weller, D.M.G. 1987. Reproduction in mallards fed selenium. Environ. Toxicol. Chem. 6, 423-433.

Hoffman, D.J. 2002. Role of selenium toxicity and oxidative stress in aquatic birds. Aquat. Toxicol. 57, 11-26.

Hoffman, D.J., Sanderson, D.J., LeCaptain, L.J., Cromartie, E., Pendleton, G.S. 1991. Interactive effects of boron, selenium and dietary protein on survival, growth, and physiology in mallard duckling. Arch. Environ. Contam. Toxicol. 20, 288-294.

Hopkins, B.C., Willson, J.D., Jopkins, W.A. 2013. Mercury exposure is associated with negative effects on turtle reproduction. Environ. Sci. Technol. 47, 2416-2422.

Hopkins, W.A., Staub, B.P., Baionno, J.A., Jackson, B.P., Roe, J.H., Ford, N.B. 2004. Trophic and maternal transfer of selenium in brown snakes (Lamprophis fuliginosus). Ecotoxicol. Environ. Saf. 58, 285-293.

Hudson, S.B., Kluever, B.M., Webb, A.C., French, S.S. 2020. Steroid hormones, energetic state, and immunocompetence vary across reproductive contexts in a parthenogenetic lizard. Gen. Comp. Endocrinol. 288, 113372.

Kew, M.C. 2000. Serum aminotransferase concentration as evidence of hepatocellular damage. The Lancet 355(9204), 591-592.

Jeffree, R.A., Markich, S.J., Twining, J.R. 2001. Element concentrations in the flesh and osteoderms of Estuarine Crocodiles (Crocodylus porosus) from the Alligator Rivers Region, Northern Australia: biotic and geographic effects. Arch. Environ. Contam. Toxicol. 40, 236245. 
Kasonga, T.K., Coetzee, M.A.A., Kamika, I., Ngole-Jeme, V.M., Momba, M.N.B. 2021. Endocrine-disruptive chemicals as contaminants of emerging concern in wastewater and surface water: a review. J. Environ. Manag. 277, 111485.

Köhrle, J., Jakob, F., Comtempré, B., Dumont, J.E. 2005. Selenium, the Thyroid, and the Endocrine System. Endocr. Rev. 26(7): 944-984.

Komoroske, L.M., Lewison, R.L., Seminoff, J.A., Deheyn, D.D., Dutton, P.H. 2011. Pollutants and the health of green sea turtles resident to an urbanized estuary in San Diego, CA. Chemophere 84, 544-552.

Kramer, H.J., Gonick, H.C., Lu, E. 1986. In vitro inhibition of Na-K-ATPase by trace metals: relation to renal and cardiovascular damage. Nephron 44(4), 329-336.

Lance, V.A., Horn, T.R., Elsey, R.M., de Peyster, A. 2006. Chronic incidental lead ingestion in a group of captive-reared alligators (Alligator mississippiensis): possible contribution to reproductive failure. Com. Biochem. Physiol. C 142, 30-35.

Lemaire, J., Brischoux, F., Marquis, O., Mangione, R., Bustamante, P. 2021. Variation of total mercury concentrations in different tissues of three neotropical caimans: Implications for minimally invasive biomonitoring. Arch. Environ. Contam. Toxicol. https://doi.org/10.1007/s00244-021-00846-y

Lemaire, J., Bustamante, P., Marquis, O., Caut, S., Brischoux, F. 2021a. Influence of sex, size and trophic level on blood Hg concentrations in Black caiman, Melanosuchus niger (Spix, 1825) in French Guiana. Chemosphere 262, 127819.

Lemaire, J., Marquis, O., Bustamante, P., Mangione, R., Brischoux, F. 2021b. I got it from my mother: Inter-nest variation of mercury concentration in neonate Smooth-fronted Caiman (Paleosuchus trigonatus) suggests maternal transfer and possible phenotypical effects. Environ. Res. 194, 110494.

Lemly, A.D. 2004. Aquatic selenium pollution is a global environmental safety issue. Ecotox. Environ. Saf. 59, 44-56.

Lin, H.V., Accili, D. 2011. Hormonal regulation of hepatic glucose production in health and disease. Cell. Metab. 14(1), 9-19.

Lock, R.A., Cruijsen, P.M.J.M., van Overbeeke, A.P. 1981. Effects of mercuric chloride and methylmercuric chloride on the osmoregulatory function of the gills in Rainbow Trout, Salmo gairdneri Richardson. Comp. Biochem. Physiol. 68, 151-159. 
Lormée, H., Jouventin, P., Trouvé, C., Chastel, O. 2003. Sex-specific patterns in baseline corticosterone and body condition changes in breeding Red-footed Boobies. Sula sula. Ibis $145,212-219$.

Magour, S. 1986. Studies on the inhibition of brain synaptosomal $\mathrm{Na}+/ \mathrm{K}+-\mathrm{ATPase}$ by mercury chloride and methyl mercury chloride. Arch. Toxicol. 9, 393-396.

Maheswari, C., Maryammal, R., Venkatanarayanan, R. 2008. Hepatoprotective activity of Orthosiphon stamineus on liver damage caused by paracetamol in rats. Jordan J. Biol. Sci. 1(3), 105-108.

Marrugo-Negrete, J., Durango-Hernández, J., Calao-Ramos, C., Urango-Cárdenas, I., Dìez, S. 2019. Mercury levels and genotoxic effect in caimans from tropical ecosystems impacted by gold mining. Sci. Total Environ. 664, 899-907.

Martemyanov, V.I., Poddubnaya, N.Y. 2020. Regulation ranges and patterns of adaptation to hyponatremia by cells of various organs and tissues of vertebrate animals. Bratisl. Med. J. $121(3), 218-224$.

Mazzotti, F.J., Dunson, W.A. 1989.Osmoregulation in Crocodilians. Amer. Zool. 29, 903-920.

Meillère, A., Brischoux, F., Bustamante, P., Michaud, B., Parenteau, C., Marciau, C., Angelier, F. 2016. Corticosterone levels in relation to trace element contamination along an urbanization gradient in the common blackbird (Turdus merula). Sci. Total Environ. 566$567,93-101$.

Meyer, E., Eagles-Smith, C.A., Sparling, D., Blumenshine, S. 2014. Mercury exposure associated with altered plasma thyroid hormones in the declining Western Pond Turtle (Emys marmorata) from California Mountain Streams. Environ. Sci. Technol. 48, 2989-2996.

Monclús, L., Shore, R.F., Krone, O. 2020. Lead contamination in raptors in Europe: A systematic review and meta-analysis. Sci. Total Environ. 748, 141437.

Moore, C.S., Cristol, D.A., Maddux, S.L., Varian-Ramos, C.W., Bradley, E.L. 2014. Lifelong exposure to methylmercury disrupts stress-induced corticosterone response in Zebra Finches (Taeniopygia guttata). Environ. Toxicol. Chem. 33(5), 1072-1076.

Morcillo, P., Esteban, M.A., Cuesta, A. 2017. Mercury and its toxic effects on fish. AIMS Environ. Sci. 4(3), 386-402.

Naderi, M., Puar, P., Zonouzi-Marand, M., Chivers, D.P., Niyogi, S., Kwong, R.W.M. 2021. A comprehensive review on the neuropathophysiology of selenium. Sci. Total Environ. 767, 144329. 
Nilsen, F.M., Dorsey, J.E., Lowers, R.H., Guillette Jr., L.J., Long, S.E., Bowden, J.A., Schock, R.B. 2017a. Evaluating mercury concentrations and body condition in American alligators (Alligator mississippiensis) at Merritt Island national Wildlife Refuge (MINWR), Florida. Sci. Total Environ. 607-608, 1056-1064.

Nilsen, F.M., Kassim, B.L., Delaney, J.P., Lange, T.R., Brunell, A.M., Guillette Jr., L.J., Long, S.E., Schock, T.B. 2017b. Trace elements biodistribution in the American alligator (Alligator mississippiensis). Chemosphere 181, 343-351.

Noyes, P.D., McElwee, M.K., Miller, H.D., Clark, B.W., Van Tiem, L.A., Walcott, K.C., Erwin, K.N., Levin, E.D. 2009. The toxicology of climate change: Environmental contaminants in a warming world. Environ. Int. 35, 971-986.

Obrist, D., Kirk, J.L., Zhang, L., Sunderland, E.M., Jiskra, M., Selin, N.E. 2018. A review of global environmental mercury processes in response to human and natural pertirbations: Changes of emissions, climate and land use. Ambio 47, 116-140.

Ohi, G., Nishigaki, S., Seki, H., Tamura, Y., Maki, T., Minowa, K., Shimamura, Y., Mizoguchi, I. 1980. The protective potency of marine animal meat against the neurotoxicity of methylmercury: its relationship with the organ distribution of mercury and selenium in the rat. Food Cosmet. Toxicol. 18, 139-145.

Ortiz, D.A., Dueñas, J.F., Villamarín, F., Ron, S.R. 2020. Long-term monitoring reveals population decline of Spectacled Caimans (Caiman crocodilus) at a Black-Water Lake in Ecuadorian Amazon. J. Herpetol. 54(1), 31-38.

Pain, D.J., Mateo, R., Green, R.E. 2019. Effects of lead from ammunition on birds and other wildlife: a review and update. Ambio 48, 935-953.

Pattee, O., Pain, D. 2003. Lead in the environment. In Handbook of ecotoxicology, eds. Hoffman, D.J., Rattner, B.A., Burton Jr., G.A., Cairns Jr., J. Second ed., Boca Raton, Florida, USA: CRC Press. pp. 373-408.

Patterson, J.H., 2011. The impact of hyponatremia. Pharmacotherapy: The Journal of Human Pharmacology and Drug Therapy, 31(5P2), 5S-8S.

Pirrone, N., Cinnirella, S., Feng, X., Finkelman, R.B., Friedli, H.R., Leaner, J., Mason, R., Mukherjee, A.B., Stracher, G., Streets, D.G., Telmer, K. 2010. Global mercury emissions to the anthropogenic and natural sources. Atmos. Chem. Phys. 10, 5951-5964.

Qian, F., Misra, S., Prabhu, K.S. 2020. Selenium and selenoproteins in prostanoid metabolism and immunity. Crit. Rev. Biochem. Mol. Biol. 54(6), 484-516. 
Rahman, M.M., Hossain, K.F.B., Banik, S., Sikder, M.T., Akter, M., Bondad, S.E.C., Rahaman, M.S., Hosokawa, T., Saito, T., Kurasaki, M. 2019. Selenium and zinc protections against metal-(loids)-induced toxicity and disease manifestations: A review. Ecotoxicol. Environ. Saf. 168, 146-163.

Ramauge, M., Pallud, S., Esfandiari, A., Gavaret, J.M., Lennon, A.M., Pierre, M., Courtin, F. 1996. Evidence that type III iodothyronine deiodinase in rat astrocyte is a selenoprotein. Endocrinology 137, 3021-3025.

Ralston, N.V.C., Raymond, L.J. 2010. Dietary selenium's protective effects against methylmercury toxicity. Toxicology 278, 112-123.

Ralston, C.R., Blackwell III, J.L., Ralston, N.V.C. 2006. Effects of dietary selenium and mercury on house crickets (Acheta domesticus L.): implications of environmental co-exposures. Environ. Bioindicators 1, 98-109.

Rayman, M. 2000. The importance of selenium to human health. Lancet 356, 233-241.

Richardson, S.D., Kimura, S.Y. 2017. Emerging environmental contaminants: Challenges facing our next generation and potential engineering solutions. Environ. Technol. Innov. 8, 40-56.

Rowe, C.L., Hopkins, W.A., Congdon, J.D. 2002. Ecotoxicological implications of aquatic disposal of coal combustion residues in the united states: a review. Environ. Monit. Assess. $80,207-276$.

Roy, M., Kiremidjian-Schumacher, L., Wishe, H.I., Cohen, M.W., Stotzky, G. 1995. Supplementation with selenium restores age-related decline in immune cell function. Proc. Soc. Exp. Biol. Med. 209, 369-375.

Sastry, K.V., Sharma, K. 1980. Mercury induced haematological and biochemical anomalies in Ophiocephalus (Channa) punctatus. Toxicol. Lett. 5, 245-249.

Scheuhammer, A.M., Basu, N., Burgess, N.M., Elliott, J.E., Campbell, G.D., Wayland, M., Rodrigue, J. 2008. Relationships among mercury, selenium and neurochemical parameters in common loons (Gavia immer) and bald eagles (Haliaeetus leucocephalus). Ecotoxicology $17,93-101$.

Scheuhammer, A.M., Meyer, M.W., Sandheinrich, M.B., Murray, M.W. 2007. Effects of environmental methylmercury on the health of wild birds, mammals, and fish. Ambio. 36 (1), 12-18.

Schmidt-Nielsen, K. 1983. Animal physiology: adaptations and environments. Cambridge Univ. Press. 
Schneider, L., Eggins, S., Maher, W., Vogt, R.C., Krikowa, F., Kinsley, L., Eggins, S.M., Da Silveira, R. 2015. An evaluation of the use of reptile dermal scutes as a non-invasive method to monitor mercury concentrations in the environment. Chemosphere 119, 163-170.

Schneider, L., Maher, W., Green, A., Vogt, R. 2013. Mercury contamination in reptiles: An emerging problem with consequences for wild life and human health. In: Kim, K., Brown, R.J.C. Mercury: Sources, Applications and Health Impacts, Nova Science Publishers, Inc., pp. 173-232.

Scott, A.K., Phillips, D.J., Keller, C.R., Karastsoreos, I.N. Role of corticosterone in altered neurobehavioral responses to acute stress in a model of compromised hypothalamicpituitary-adrenal axis function. Psychoneuroendocrinology 102, 248-255.

Somaweera, R., Nifong, J., Rosenblatt, A., Brien, M.L., Combrink, X., Elsey, R.M., Grigg, G., Magnusson, W.E., Mazzotti, F.J., Pearcy, A., Platt, S.G., Shirley, M.H., Tellez, M., Van der Ploeg, J., Webb, G., Whitaker, R., Webber, B.L. 2020. The ecological importance of crocodylians: towards evidence-based justification for their conservation. Biol. Rev. 95 (4), 936-959.

Soto, M., Lewis, R., Curtis, J.T. 2019. Chronic exposure to inorganic mercury alters stress responses in male prairie voles (Microtus ochrogaster). Hom. Behav. 109, 53-55.

Sugiura, Y., Tamai, Y., Tanaka, H. 1978. Selenium protection against mercury toxicity: high binding affinity of methylmercury by selenium-containing ligands in comparison with sulfur-containing ligands. Bioorg. Chem. 9(2), 167-180.

Suzuki, K.T. 1997. Equimolar Hg-Se complex binds to selenoproteins P. Biochem. Biophys. Res. Commun. 231, 7-11.

Tan, S.W., Meiller, J.C., Mahaffey, K.R. 2009. The endocrine effects of mercury in humans and wildlife. Crit. Rev. Toxicol. 39(3), 228-269.

Targarona, R.R., Soberón, R.R., Cotayo, L., Tabet, M.A., Thorbjarnarson, J. 2008. Crocodylus rhombifer. The IUCN Red List of Threatened Species 2008: e.T5670A112902585.

Tartu, S., Goutte, A., Bustamante, P., Angelier, F., Moe, B., Clément-Chastel, C., Bech, C., Gabrielsen, G.W., Chastel, O. 2013. To breed or not to breed: endocrine response to mercury contamination by an Arctic seabird. Biol. Lett. 9, 20130317.

Taylor, D., Dalton, C., Hall, A., Woodroofe, M.N., Gardiner, P.H.E. 2009. Recent developments in selenium research. Br. J. Biomed. Sci. 66, 107-116. 
Trillanes, C.E., Pérez-Jiménez, J.C., Rosíles-Martínez, R., González-Jáuregui, M. 2014. Metals in the caudal scutes of Morelet's Crocodile (Crocodylus moreletii) from the Southern Gulf of Mexico. Bull. Environ. Contam. Toxicol. 93, 423-428.

Ullah, H., Liu, G., Yousaf, B., Ali, M.U., Irshad, S., Abbas, Q., Ahmad, R. 2019. A comprehensive review on environmental transformation of selenium: recent advances and research perspectives. Environ. Geochem. Health 41, 1003-1035.

Van Weerd, M., Pomaro, C., de Leon, J., Antolin, R., Mercado, V. 2016. Crocodylus mindorensis. The Red List of Threatened Species 2016: e.T5672A3048281.

Vieira, L.M., da S. Nunes, V., do A. Amaral, M.C., Oliveira, A.C., Hauser-Davis, R.A., Campos, R.C. 2011. Mercury and methyl mercury ratios in caimans (Caiman crocodilus yacare) from the Pantanal area, Brazil. J. Environ. Monit. 13, 280-287.

Vizuete, J., Pérez-López, M., Míguez-Santiyán, M.P., Hernández-Moreno., D. 2018. Mercury $(\mathrm{Hg})$, Lead (Pb), Cadmium (Cd), Selenium (Se), and Arsenic (As) in liver, kidney, and feathers of Gulls: A review. In: de Voogt P. (eds) Reviews of Environmental Contamination and Toxicology Volume 247, Springer.

Wani, A.L., Ara, A., Usmani, J.A. 2015. Lead toxicity: a review. Interdiscip. Toxicol. 8, 55-64.

Warner, J.K., Combrink, X., Myburgh, J.G., Downs, C.T. 2016. Blood lead concentrations in freeranging Nile crocodiles (Crocodylus niloticus) from South Africa. Ecotoxicology 25, 950-958.

Whitney, M.C., Cristol, D.A. 2017. Impacts of sublethal mercury exposure on birds: a detailed review. Rev. Environ. Contam. Toxicol. 244, 113-163.

Yanochko, G.M., Jagoe, C.H., Brisbin Jr., I.L. 1997. Tissue mercury concentrations in Alligators (Alligator mississippiensis) from the Florida Everglades and the Savannah River site, South Carolina. Arch. Environ. Contam. Toxicol. 32, 323-328.

Zahir, F., Rizwi, S.J., Haq, S.K., Khan, R.H. 2005. Low dose mercury toxicity and human health. Environ. Toxicol. Pharmacol. 20, 351-360.

Zheng, N., Wang, S., Dong, W., Hua, X., Li, Y., Song, X., Chu, Q., Hou, S., Li, Y. 2019. The toxicological effects of mercury exposure in marine fish. Bull. Environ. Contam. Toxicol. $102,714-720$. 
Table 1. Morphometrics, biochemistry parameters and trace element concentrations of the Spectacled Caiman (Caiman crocodilus) from French Guiana.

\begin{tabular}{|c|c|c|c|}
\hline & \multicolumn{3}{|c|}{ Caiman crocodilus } \\
\hline & $\mathbf{N}$ & Mean \pm SD & Min - Max \\
\hline \multicolumn{4}{|l|}{ Morphometric parameters } \\
\hline Snout-Vent-Length $(S V L)^{1}$ & 23 & $35.9 \pm 7.7$ & $20.2-48.5$ \\
\hline Weight $(W)^{2}$ & 23 & $1443 \pm 950$ & $250-3950$ \\
\hline \multicolumn{4}{|l|}{ Metal concentrations } \\
\hline$H g^{3}$ & 21 & $0.676 \pm 0.414$ & $0.168-1.532$ \\
\hline$S e^{3}$ & 21 & $1.35 \pm 0.30$ & $0.76-1.92$ \\
\hline $\mathrm{Se}: \mathrm{Hg}$ & 21 & $7.90 \pm 5.85$ & $1.45-21.54$ \\
\hline$P b^{3}$ & 21 & $0.13 \pm 0.06$ & $0.04-0.28$ \\
\hline \multicolumn{4}{|l|}{ Biochemistry parameters } \\
\hline Total calcium $\left(\mathrm{Ca}^{++}\right)^{4}$ & 23 & $10.6 \pm 0.9$ & $9.1-12.5$ \\
\hline Potassium $\left(K^{+}\right)^{5}$ & 22 & $4.6 \pm 0.7$ & $3.4-6.1$ \\
\hline Sodium $\left(\mathrm{Na}^{+}\right)^{5}$ & 23 & $139.1+7.2$ & $126-152$ \\
\hline Chlorine $\left(\mathrm{Cl}^{-5}\right)^{5}$ & 10 & $103.9 \pm 6.0$ & $93-112$ \\
\hline Phosphorus $(P)^{4}$ & 14 & $52 \pm 11$ & $35-74$ \\
\hline Uric acid $(U A)^{4}$ & 14 & $14 \pm 8.0$ & $6.0-33$ \\
\hline Glucose $(G L U)^{4}$ & 23 & $662 \pm 152$ & $330-960$ \\
\hline Total bilirubin (TBIL) ${ }^{4}$ & 10 & $2.5 \pm 1.0$ & $20-30$ \\
\hline Total protein $(T P)^{6}$ & 23 & $49 \pm 8.0$ & $35-72$ \\
\hline Creatine kinase $(C K)^{7}$ & 13 & $3245 \pm 1420$ & $1192-6148$ \\
\hline Aspartate aminotransferase $(A S T)^{7}$ & 23 & $133.4 \pm 35.0$ & $88-229$ \\
\hline Alanine aminotransferase $(A L T)^{7}$ & 10 & $43.0 \pm 10.9$ & $27-66$ \\
\hline Alkaline phosphatase $(A L P)^{7}$ & 8 & $28.6 \pm 9.6$ & $16-46$ \\
\hline Total carbon dioxide $\left(\mathrm{tCO}_{2}\right)^{8}$ & 10 & $15.8 \pm 4.6$ & $8-24$ \\
\hline Corticosterone $^{9}$ & 21 & $27.72 \pm 14.01$ & $7.98-53.61$ \\
\hline
\end{tabular}

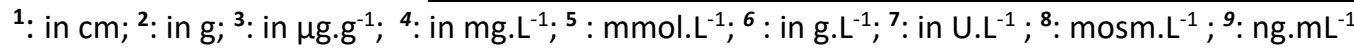


Table 2. Summary statistics of linear regression between morphometrics, metal concentrations and biochemistry parameters in the Spectacled Caiman (Caiman crocodilus) in French Guiana. Bold denotes significant relationship $(p<0.05)$ and arrows indicate a positive or negative correlation.

\begin{tabular}{|c|c|c|c|c|c|c|c|c|c|c|c|c|}
\hline Parameters & & & & & Se & & & & & & $P b$ & \\
\hline Caiman crocodilus & $n$ & $R^{2}$ & $p$ & $n$ & $R^{2}$ & $p$ & $n$ & $R^{2}$ & $p$ & $n$ & $R^{2}$ & $p$ \\
\hline Snout-vent length (SVL) & 21 & 0.143 & 0.091 & 20 & 0.091 & 0.198 & 20 & 0.161 & 0.080 & 21 & 0.290 & $0.012 \uparrow$ \\
\hline Weight (W) & 21 & 0.163 & 0.070 & 20 & 0.130 & 0.118 & 20 & 0.197 & 0.050 & 21 & 0.129 & 0.110 \\
\hline Total calcium $\left(\mathrm{Ca}^{++}\right)$ & 21 & 0.112 & 0.138 & 20 & 0.017 & 0.587 & 20 & 0.058 & 0.307 & 21 & 0.122 & 0.121 \\
\hline Potassium $\left(\mathrm{K}^{+}\right)$ & 20 & 0.045 & 0.370 & 19 & 0.074 & 0.259 & 19 & 0.058 & 0.319 & 20 & 0.186 & 0.057 \\
\hline Sodium $\left(\mathrm{Na}^{+}\right)$ & 21 & 0.345 & $0.005 \downarrow$ & 20 & 0.184 & 0.059 & 20 & 0.378 & $0.004 \uparrow$ & 21 & 0.001 & 0.897 \\
\hline Chlorine $\left(\mathrm{Cl}^{-}\right)$ & 9 & 0.437 & 0.053 & 9 & 0.109 & 0.386 & 9 & 0.395 & 0.070 & 9 & 0.041 & 0.602 \\
\hline Phosphorus (P) & 13 & 0.091 & 0.315 & 12 & 0.030 & 0.592 & 12 & 0.062 & 0.436 & 13 & 0.099 & 0.295 \\
\hline Uric acid (UA) & 13 & 0.009 & 0.757 & 12 & 0.161 & 0.197 & 12 & 0.079 & 0.376 & 13 & 0.032 & 0.562 \\
\hline Glucose (GLU) & 21 & 0.014 & 0.612 & 20 & 0.073 & 0.251 & 20 & 0.031 & 0.455 & 21 & 0.239 & $0.025 \downarrow$ \\
\hline Total bilirubin (TBIL) & 9 & 0.2085 & 0.217 & 9 & 0.082 & 0.455 & 9 & 0.200 & 0.228 & 9 & 0.096 & 0.418 \\
\hline Total protein (TP) & 21 & 0.008 & 0.700 & 20 & 0.024 & 0.514 & 20 & 0.015 & 0.611 & 21 & 0.006 & 0.740 \\
\hline Creatine kinase (CK) & 13 & 0.000 & 0.972 & 12 & 0.014 & 0.716 & 12 & 0.005 & 0.828 & 13 & 0.003 & 0.866 \\
\hline Aspartate aminotransferase (AST) & 21 & 0.003 & 0.824 & 20 & 0.078 & 0.232 & 20 & 0.013 & 0.629 & 21 & 0.162 & 0.070 \\
\hline Alanine aminotransferase (ALT) & 9 & 0.001 & 0.929 & 9 & 0.002 & 0.910 & 9 & 0.002 & 0.921 & 9 & 0.740 & $0.003 \uparrow$ \\
\hline Alkaline phosphatase (ALP) & 8 & 0.601 & $0.024 \downarrow$ & 8 & 0.035 & 0.655 & 8 & 0.477 & 0.058 & 8 & 0.003 & 0.894 \\
\hline Total carbon dioxide $\left(\mathrm{tCO}_{2}\right)$ & 9 & 0.142 & 0.318 & 9 & 0.028 & 0.667 & 9 & 0.125 & 0.351 & 9 & 0.175 & 0.263 \\
\hline Corticosterone & 19 & 0.276 & $0.021 \downarrow$ & 18 & 0.090 & 0.228 & 18 & 0.272 & $0.026 \uparrow$ & 19 & 0.064 & 0.295 \\
\hline
\end{tabular}



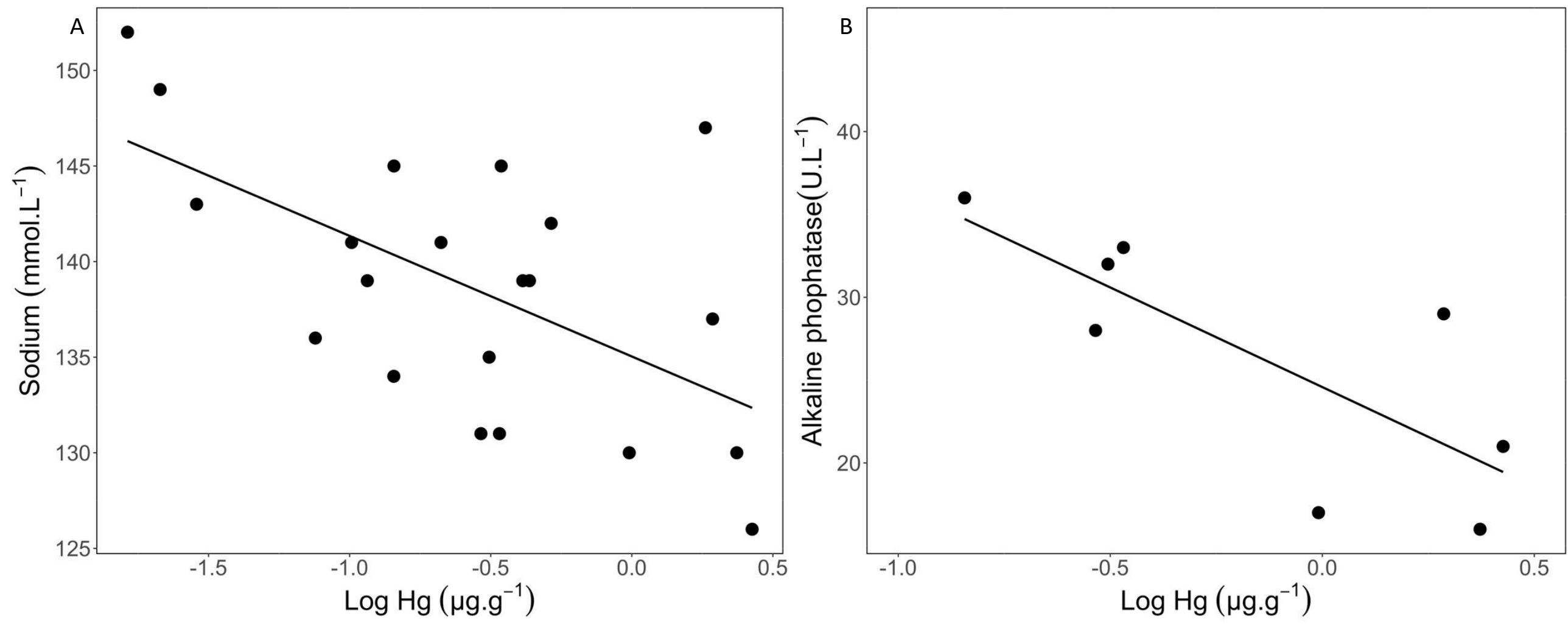

Figure 1. Relation between $\mathrm{Hg}$ concentration ( $\log \mu \mathrm{g} \cdot \mathrm{g}^{-1} \mathrm{dw}$ ) and $(\mathbf{A})$ sodium (mmol. $\left.\mathrm{L}^{-1}, \mathrm{R}^{2}=0.345, \mathrm{p}=0.005\right)$ and $(\mathbf{B})$ alkaline phosphatase (U.L-

${ }^{1}, R^{2}=0.601, p=0.024$ ) in the blood of the Spectacled Caiman (Caiman crocodilus) from French Guiana. 


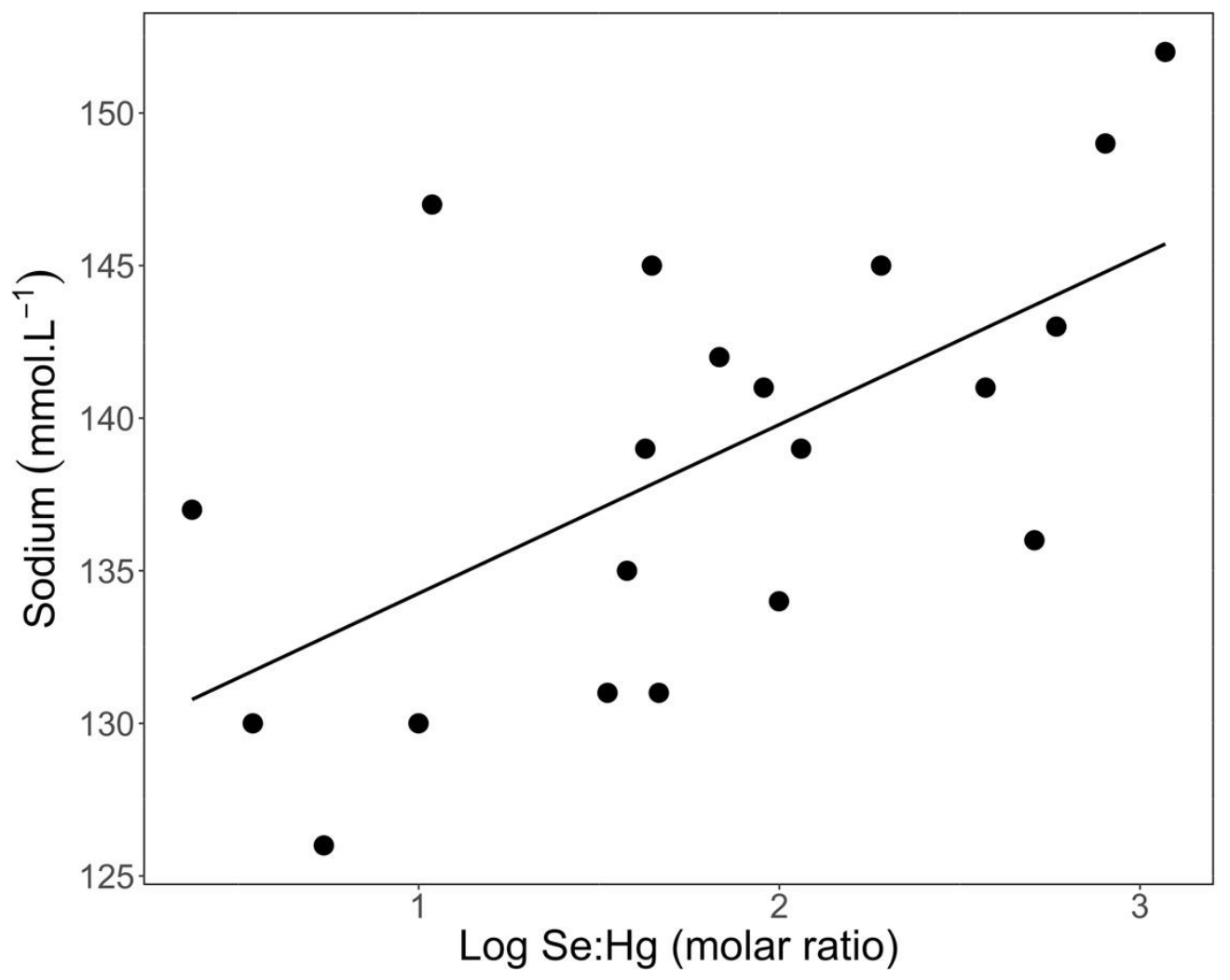

Figure 2. Relation between Se:Hg molar ratio and sodium (mmol. $\left.\mathrm{L}^{-1}, \mathrm{R}^{2}=0.378, \mathrm{p}=0.004\right)$ in the blood of the Spectacled Caiman (Caiman crocodilus) from French Guiana. 

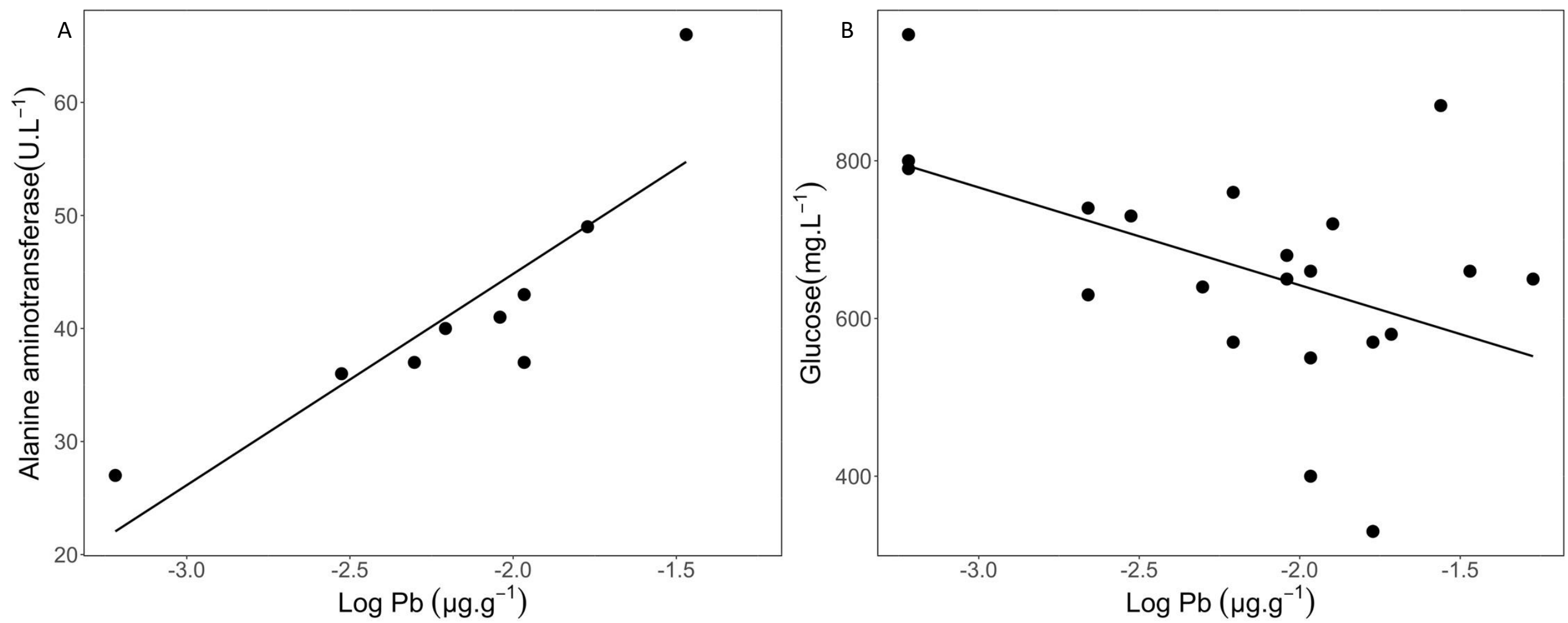

Figure 3. Relation between $\mathrm{Pb}$ concentration ( $\log \mu \mathrm{g} \cdot \mathrm{g}^{-1} \mathrm{dw}$ ) and $(A)$ Alanine aminotransferase $\left(U \cdot \mathrm{L}^{-1}, \mathrm{R}^{2}=0.740, \mathrm{p}=0.003\right)$ and $(B) \mathrm{Glucose}$ (mg. $\mathrm{L}^{-1}, \mathrm{R}^{2}=0.239, \mathrm{p}=0.025$ ) in the blood of the Spectacled Caiman (Caiman crocodilus) from French Guiana. 